\title{
SYNTHESIS OF DINUCLEOTIDES CATALYZED BY THE GUANYL-RN-ASE OF ACTINOMYCETES
}

\author{
R. F. Renkhof, U. V. Beika, and É. Ya. Gren
}

Khimiya Prirodnykh Soedinenii, Vol. 6, No. 1, p. 145, 1970

UDC 547.963 .3

In recent years, considerable successes have been achieved in the enzymatic synthesis of oligonucleotides by pancreatic $\mathrm{RN}$-ase [1], and $\mathrm{RN}$-ase $\mathrm{T}_{1}$. In addition, the synthesizing activity of the guanyl-RN-ase of actinomycetes has been studied [3]. We have isolated a guanosine-specific ribonuclease from the culture liquid of the actinomycete Actinomyces nurse and have carried out experiments in order to elucidate the synthesizing capacity of this enzyme on the basis of the synthesis of all the guanosine-containing dinucleoside phosphates (GpNp) from guanosine $2^{\prime}, 3^{\prime}-$ cyclophosphate $(\mathrm{G}>\mathrm{p})$ and nucleotides $\left(\mathrm{N}_{\mathrm{p}}\right)$.

The reaction was carried out mainly by a published method [3]. The optimum yield of dinucleotides was found after $6 \mathrm{hr}$ at a ratio of $\mathrm{G}>\mathrm{p}$ to $\mathrm{Np}$ to guanyl-RN-ase of $2 \mu \mathrm{M}: 30 \mu \mathrm{M}: 600$ activity units in $0.2 \mathrm{ml}$ (besides $\mathrm{GpGp}$ ) of $0.05 \mathrm{M}$ phosphate buffer, $\mathrm{pH} 7.2$, at $5^{\circ} \mathrm{C}$. After the reaction the enzyme was inactivated by the addition of concentrated formic acid to a final concentration of $0.5 \mathrm{M}$.

The components of the reaction mixture were separated by chromatography $(40 \mathrm{hr})$ on preparative Whatman $3 \mathrm{MM}$ paper in System (1): isobutyric acid-0.5 $\mathrm{N} \mathrm{NH}_{4} \mathrm{OH}(10: 6)$, pH 3.6 [3]. The spots of the dinucleotides were cut out, washed with ether, and eluted with water. The products of synthesis were identified spectrophotometrically [4] and by hydrolysis with guanyl-RN-ase [3], with subsequent chromatography of the cleavage products on FNLL (GDR) paper, GpCp in System (2): isopropanol- $\mathrm{HCl}-\mathrm{H}_{2} \mathrm{O}(170: 41 \mathrm{ml}$; water to $250 \mathrm{ml}$ ) and then in System (3): ethanol-1 $\mathrm{M}$ ammonium acetate, $\mathrm{pH} 3.8$ (7.5:3); and GpUp, GpAp, and GpGp in System (4): ethanol-1 M ammonium acetate, $\mathrm{pH}$ $7.5(7.5: 8)$ and then in System 3.

The yield of the dinucleotides GpCp and GpUp amounted to 30-35\%, and that of GpAp 10\% of the amount of $\mathrm{G}>\mathrm{p}$ taken; GpGp was identified but was not determined quantitatively.

Thus we have confirmed the capacity of the guanyl-RN-ase of Actinomyces nurse for catalyzing the formation of a phosphodiester bond on the basis of the synthesis of all the guanosine-containing dinucleoside diphosphates and have developed a fairly convenient method for the enzymatic preparation of these dinucleotides in small amounts.

\section{R E FERENCES}

1. N. S. Tikhomirova-Sidorova, G. E. Ustyuzhanin, and É. M. Kogan, Biokhim., 32, 867, 1967.

2. T. Sekiya, I. Furuichi, M. Ioshida, and T. Ukita, J. Biochem. , 63, 541, 1968.

3. N. M. Abrosimova-Amel'yanchik, R. I. Tatarskaya, and A. A. Baev, Mol. biol., 1, 307, 1967.

4. T. V. Venkstern and A. A. Baev, Absorption Spectra of the Minor Bases, Their Nucleosides and Nucleotides, and Some Oligoribonucleotides [in Russian], Moscow, 1965.

29 November $\mathbb{1 9 6 9}$

Institute of Organic Synthesis, AS LatvSSR 